STIE

\title{
Marginal Propensity to Save of Workers in Textile Products Industry (TPT)
}

\author{
Khalwatul Ulya', P. Eko Prasetyo \\ Jurusan Ekonomi Pembangunan, Fakultas Ekonomi, Universitas Negeri Semarang \\ Permalink/DOI: https://doi.org/10.15294/efficient.v2i2.3080o \\ Received: December 2018 ; Accepted: March 2019; Published: Juny 2019

\begin{abstract}
The purpose of this study was to find out the desire to save the textile industry workers in Semarang Regency and the factors that influence it. This type of research is quantitative descriptive. The population in this study was Labor at 10 TPT Industries totaling 17,757. The sample was determined by 100 respondents using the Slovin formula, and was considered representative. The sampling technique used is simple random. Methods of collecting data used questionnaires, interviews and observations. Data analysis method used multiple linear regression. The variables used in this study are age, income, consumption and education level as independent variables. While the desire to save as a dependent variable. The results showed that the income variable and education level had a positive and not significant effect, the consumption variable had a negative and significant influence, the age variable had a negative and not significant effect on saving desires. Suggestions for optimizing the increase in savings, employees should be able to increase the desire to save by consuming as needed and reduce unnecessary expenses so that the amount of savings can be increased and the benefits of saving can be felt.
\end{abstract}

Keywords: Marginal Propensity to Save, Savings Function, Consumption Function.

\begin{abstract}
Abstrak
Tujuan dari penelitian ini adalah untuk mengetahui keinginan untuk menyelamatkan pekerja industri tekstil di Kabupaten Semarang dan faktor-faktor yang mempengaruhinya. Jenis penelitian ini adalah deskriptif kuantitatif. Populasi dalam penelitian ini adalah Tenaga Kerja di 1o Industri TPT dengan total 17.757. Sampel ditentukan oleh 100 responden menggunakan rumus Slovin, dan dianggap representatif. Teknik pengambilan sampel yang digunakan adalah acak sederhana. Metode pengumpulan data menggunakan kuesioner, wawancara dan observasi. Metode analisis data menggunakan regresi linier berganda. Variabel yang digunakan dalam penelitian ini adalah usia, pendapatan, konsumsi dan tingkat pendidikan sebagai variabel independen. Sedangkan keinginan untuk menabung sebagai variabel dependen. Hasil penelitian menunjukkan bahwa variabel pendapatan dan tingkat pendidikan berpengaruh positif dan tidak signifikan, variabel konsumsi berpengaruh negatif dan signifikan, variabel umur berpengaruh negatif dan tidak signifikan terhadap keinginan menabung. Saran untuk mengoptimalkan peningkatan tabungan, karyawan harus dapat meningkatkan keinginan untuk menabung dengan mengkonsumsi sesuai kebutuhan dan mengurangi biaya yang tidak perlu sehingga jumlah tabungan dapat ditingkatkan dan manfaat dari tabungan dapat dirasakan.
\end{abstract}

Kata Kunci: Kecenderungan Marginal untuk Menyelamatkan, Fungsi Tabungan, Fungsi Konsumsi.

How to Cite: Ulya, K., \& Prasetyo, P. (2019). Marginal Propensity to Save of Workers in Textile Products Ind EFFICIENT Indonesian Journal of Development Economics, 2(2), 413-423. https://doi.org/10.15294/efficient.v2i2.30

(C) 2019 Semarang State University. All rights reserved

\footnotetext{
Alamat Korespondensi :

Alamat: Gedung L2 Lantai 2 FE Unnes

Kampus Sekaran, Gunungpati, Semarang, 50229

E-mail : efficientjournal@gmail.com
}

ISSN 2655-6197 


\section{INTRODUCTION}

Community savings, basically is part of the income received by the community that is not used for consumption or in other words, community savings are the difference between income and consumption (Sumastuti, 2009). The desire to save is only done when consumption and taxes are smaller than income. Given the important role of community savings in sustaining development financing, development economists have sought to find and formulate factors that can influence and encourage the level of community savings.

The existence of the textile industry is very important for the economy because it is one of the biggest contributors of foreign exchange and absorber of labor (Prasetyo, P. Eko, 2015). The textile industry is also a labor intensive industry (Prasetyo, P. Eko, 2015). The textile and textile products industry is more focused on a large number of workers or workers in the construction and operation and contributes a large contribution to employment (Apriliyanto, 2018).

The textile and textile products industry in Semarang Regency is a leading industry or a well-known industry in the area, where the number of workers in the industry is thus categorized as very large. With the large number of workers absorbed in the industry, is the phenomenon of the desire to save labor in the TPT industry high with the average income they get for a full month of work and their average monthly consumption they are still able or not to set aside money for them to save.

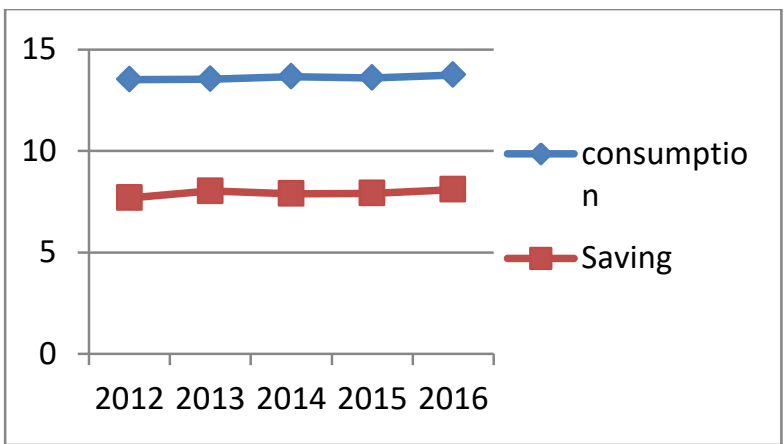

Picture 1. Comparison of Consumption and Savings in Semarang Regency in 2012-2016 Source: Semarang Regency BPS in 2016

Graph 1 describes consumption and savings expressed in units of ratios. Income is greater than consumption so that the excess income can be saved, this can be seen from the positive MPS curve. Thus in the opinion of Keynes can be interpreted, if income increases, but consumption decreases, then savings will increase. Conversely, if income increases and consumption increases, savings will decrease. The ratio used is a comparison of the value between the share of total income used for consumption and the part used for savings (Ubaidillah, 2019).

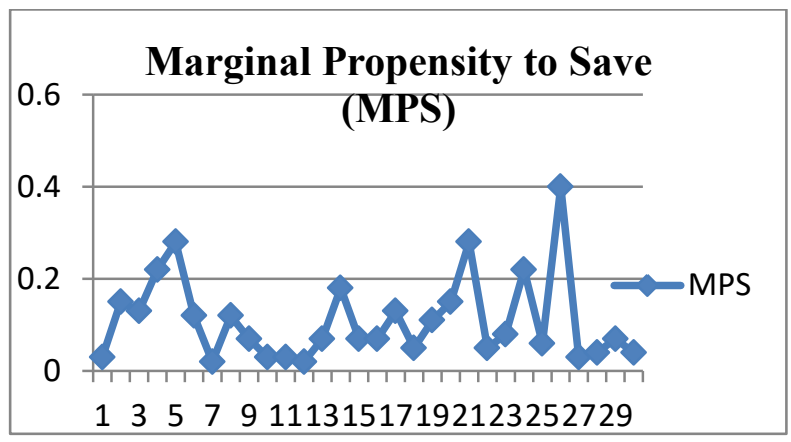

Picture 2. Marginal Propensity to Save (MPS) Labor in the TPT Industry in Semarang Regency in 2018.

Source: MPS (Data Processed), 2018. 
Based on the above graph, it can be seen that the average MPS of workers in Semarang Regency is o.11. This number still shows a low tendency to save when compared with the research of Dini Septiani (2013) with the average MPS result of $\mathbf{0 . 2 0}$. The data was obtained from 30 respondents per 10 textile industry companies in Semarang Regency.

The low level of labor savings in the textile industry in Semarang Regency according to the results of a preliminary study with preliminary research on 10 textile industry companies shows that it does not mean that workers cannot afford to save but mostly save in real assets and prefer to save money at home rather than saving at a bank. The success of increasing business in mobilizing savings in the workforce itself so that it can be more absorbed in the banking institutions must have an effort that depends on understanding the characteristics of saving behavior in the workforce itself.

Generally they save $5-10 \%$ of the total income earned. Most of these workers do not save for a period of time each month, they save if the expenses made in the month are not too much or only if there is a residual income. Most of them save their money for reuse in the same month, only a few people actually save in the bank for a long time. Consumptive behavior is one of the things that motivates people to spend their income.

Based on the description above, this study is intended to find out the desire to save labor in the TPT industry is influenced by several factors such as age, income, consumption, education level or not. This research was conducted in the TPT Industrial area in Semarang Regency by conducting initial research. And from the explanation above, the research statement in this study can be formulated as follows :

1. Does the age of workforce in the textile industry and textile products in Semarang Regency affect the desire to save?

2. Does the income of the workforce of the textile industry and textile products in Semarang Regency affect the desire to save?

3. Does the labor consumption of the textile industry and textile products in Semarang Regency affect the desire to save?

4. Does the education level of the textile industry and textiles products of Semarang Regency affect the desire to save?

\section{METHOD}

This study uses a quantitative approach. with the aim of testing the predetermined hypothesis. (Sugiyono, 2017: 8). Research designs include: population and research samples, research variables, data collection methods, validity and reliability of research instruments, and data analysis. The population used in this study are workers who are still employees of the textile and textile products industry in Semarang Regency. In this study the respondents used were the number of workers of 10 companies with a total of 17,757 workers in the textile industry in Semarang district. Then the tolerance error value used is $10 \%$ with a confidence level of $90 \%$. Samples obtained as follows:

$$
\begin{aligned}
& N \text { : 17.757 Labor } \\
& e: \quad \quad \quad \quad 10 \%, \quad n=\frac{\mathrm{N}}{1+\mathrm{N}(e)^{2}}
\end{aligned}
$$




$$
\begin{aligned}
& \mathrm{n}: \frac{17.757}{1+17.757(0,1)^{2}} \\
& \mathrm{n}: 99,439
\end{aligned}
$$

Based on the calculation of the Slovin formula above, a sample of 99,439 was obtained or rounded up to 100 people. Because of the contradictory nature of the population which tends to be homogeneous, the data taken by 100 workers as respondents can already be considered representative. The sampling technique used is simple random technique.

The research variables used in this study consisted of dependent or dependent variables $(\mathrm{Y})$, in this study the variables of saving desire. Independent or independent variable $(\mathrm{X})$, in this study include age, assessment, consumption and education level.

This study uses a multiple linear regression analysis method. This method is used to determine the effect of variable age, wages, consumption, level of education on the desire to save labor. The function of saving desire is obtained by entering the dependent variable, that is, the value of the calculation of MPS which is assumed to affect the independent variable. Independent variables consist of age variables $\left(\mathrm{X}_{1}\right)$, wages $\left(\mathrm{X}_{2}\right)$, consumption $\left(\mathrm{X}_{3}\right)$, and education level $\left(\mathrm{X}_{4}\right)$. This method uses the OLS (Ordinary Least Square) approach. The regression equation in this study are as follows:

$\mathrm{Y}=\beta_{\mathrm{o}}+\beta_{1} \mathrm{X}_{1}+\beta_{2} \mathrm{X}_{2}-\beta_{3} \mathrm{X}_{3}+\beta_{4} \mathrm{X}_{4+} \mathrm{e}_{\mathrm{i}} \ldots \ldots \ldots$ (1)

$$
\begin{aligned}
& \operatorname{LnY}=\operatorname{Ln} \beta_{o}+\beta_{1} \operatorname{LnX} X_{1} \beta_{2} \operatorname{LnX}_{2}-\beta_{3} \operatorname{LnX}_{3}+ \\
& \beta_{4} \operatorname{LnX}_{4+} e_{i}
\end{aligned}
$$

Keterangan:

$\begin{array}{ll}\mathrm{Y} & : \text { MPS } \\ \beta_{\mathrm{o}} & \text { : Constant } \\ \mathrm{X}_{1} & \text { : Age (Years) } \\ \mathrm{X}_{2} & \text { : Wages (Rupiah) } \\ \mathrm{X}_{3} & \text { : Consumption (Rupiah) } \\ \mathrm{X}_{4} & : \text { Education (Year) } \\ \text { e : Standard Error }\end{array}$

The multiple linear regression analysis used in this study is regression analysis in the form of $\mathrm{LN}$ which is found in equation 3.2. This LN method is used to find out how much influence the $\mathrm{LN}$ variable ages, $\mathrm{LN}$ wages, LN consumption, LN education level towards the desire to save labor in the textile industry in Semarang Regency.

Between MPS and MPC have a fairly strong relationship, this can be proved by using the following equation:

$$
\begin{aligned}
& S=-a+(1-b) Y \\
& 1-b=\text { MPS } \\
& b=\text { MPC }
\end{aligned}
$$

\section{Normality Test}

According to Imam Ghozali (2013: 110) the purpose of the normality test is to find out whether each data is normally distributed or not. The normality test uses the Normal P-Plot graph, the Histogram and One Graph of the 
Kolmogorov-smirnov (K-S) sample with a probability value (significance level) of 0.05 . The results of the normality test using the IBM SPSS 23 Statistic. Based on picture 3 above, it is known that the histogram graph provides a distribution pattern that deviates to the right which means that the data is normally distributed.

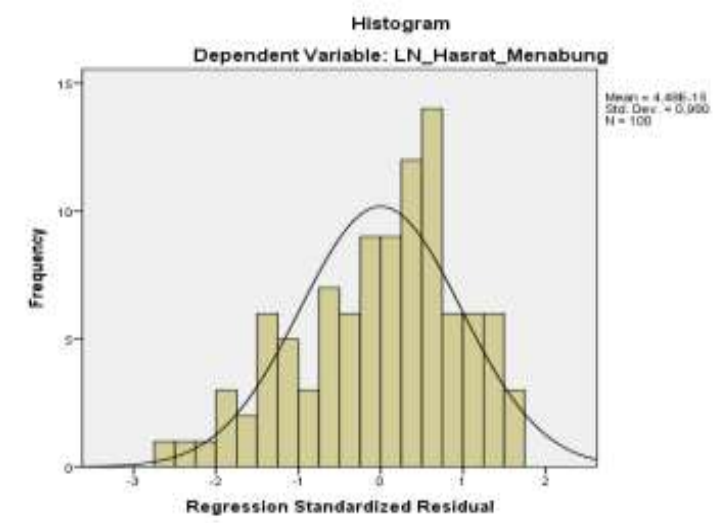

Picture 3. Histogram Graph

Source: Primary Data processed, 2018

Based on graph 4 above, it is known that the dependent variable of desire to save points on normal probability plot images tends to form and follow diagonal lines and spread around diagonal lines, so that it can be seen that the model is normally distributed.

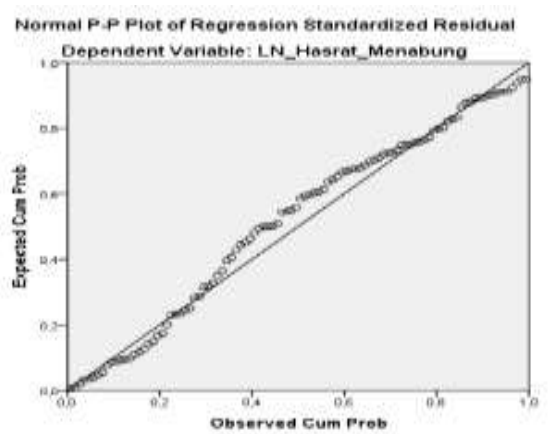

Picture 4. P-Plot Graph

Source: Primary Data processed, 2018
Based on the normality test by using one sample kolmogorov-smirnov test, the savings desire variable obtained Kolmogorov-Smirnov $\mathrm{Z}$ value and Asymp Sig (2-tailed) value of 0.056> 0.05, which means that Unstandardized Residual data are normally distributed.

Table 1. Table of the Kolmogorov-Smirnov One Sample Test

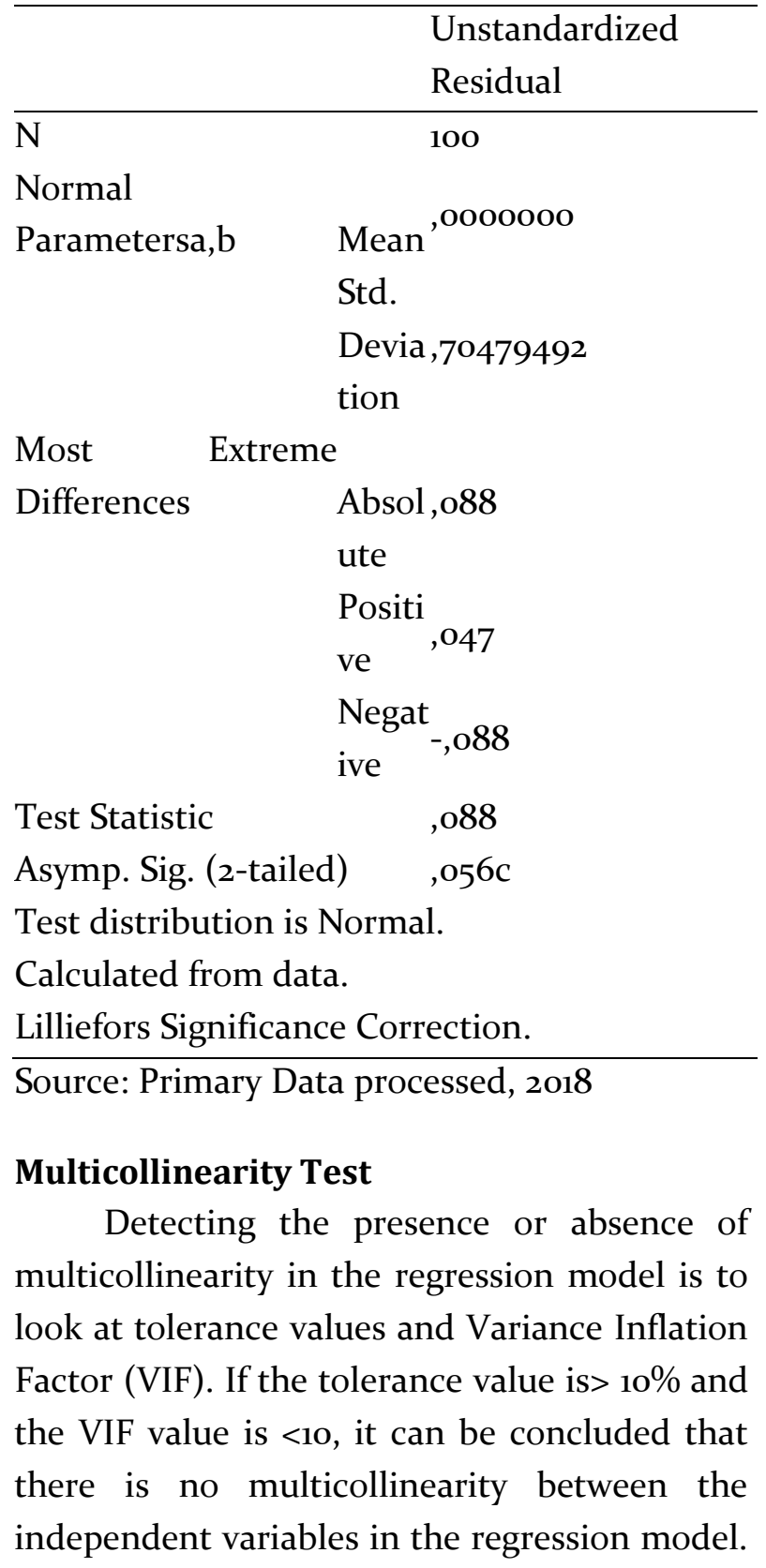


The following are the results of the multicollinearity test calculations with IBM SPSS 23 Statistics.

Table 2 above shows that each independent variable has a tolerance value $>0.1$ and VIF value $<10$. It can be concluded that there is no multicollinearity between independent variables in this regression model.

Tabel 2. Multikolinearitas

\begin{tabular}{lll}
\hline Variabel & \multicolumn{2}{l}{ Collinearity Statistics } \\
& Tolerance & VIF \\
\hline (Constant) & & \\
Ln_Age & .837 & 1.194 \\
Ln_Income & .782 & 1.279 \\
Ln_Consumption & .796 & 1.256 \\
Ln_Education & .781 & 1.281
\end{tabular}

Source: Primary Data processed, 2018

\section{Heteroscedasticity Test}

Heteroscedasticity tests can be done by observing the scatterplot graph with a pattern of dots that spread above and below the Y axis.

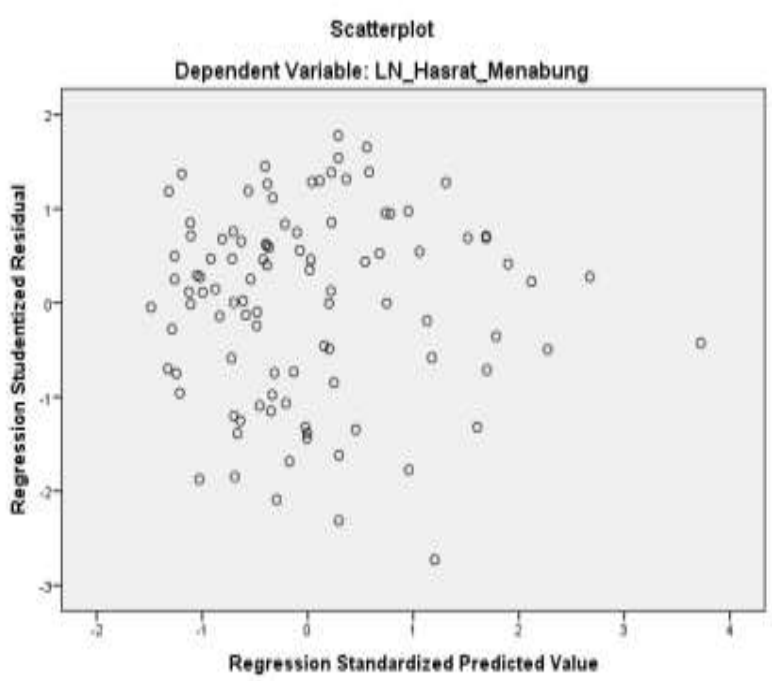

Picture 5. Scatterplot Graph

Source: Primary Data processed, 2018
Graph 5 above, shows that on the Scatterplot graph visible dots spread randomly and scattered both above and below the zero on the $\mathrm{Y}$ axis and the spread of data points does not form a wavy pattern widened and then narrows and widens again. It can be concluded that for the dependent variable and the independent variable there is no heteroscedasticity in this regression model.

\section{RESULTS AND DISCUSSION}

\section{Multiple Linear Regression Analysis}

The following are the results of the regression calculation of Ln age, Ln income, Ln consumption, and Ln level of education towards Ln saving desire by using IBM SPSS Statistic 23:

Table 3. Results of Regression Calculation

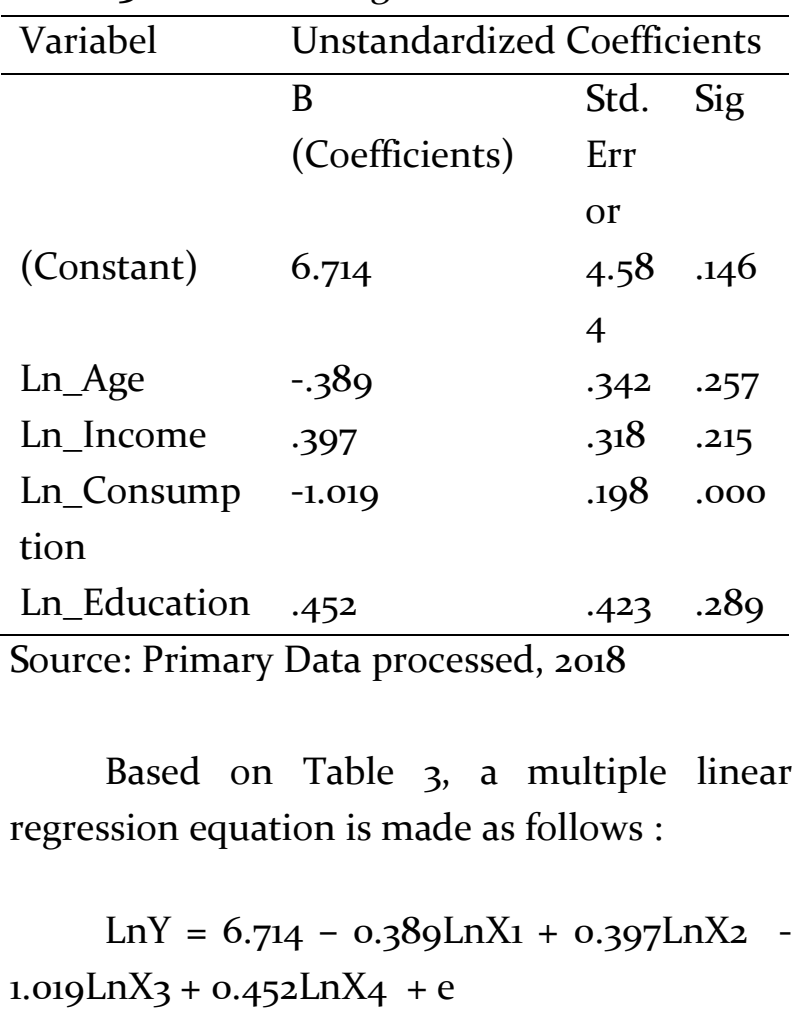




$$
\text { Ln_MPS }=6.714-0.389 \text { Ln_age }+0.397
$$

Ln_income - 1.019 Ln_consumption +0.452 Ln_education

From Equation above a constant coefficient of 6.714 means that if age $\left(\mathrm{X}_{1}\right)$, income $\left(\mathrm{X}_{2}\right)$, consumption $\left(\mathrm{X}_{3}\right)$ and education level $\left(\mathrm{X}_{4}\right)$ is $\mathrm{o}$, the value of saving desire or marginal propensity to save is 6.714. Age value $\left(\mathrm{X}_{1}\right)$ is $-0,389$, which means that every age increases by $1 \%$, the saving desire variable will decrease by $0.342 \%$. The value of income or wages $\left(\mathrm{X}_{2}\right)$ is 0.397 which means that every increase of $1 \%$ in the amount of income, the variable of saving desire will increase by $0.318 \%$. The consumption value $\left(\mathrm{X}_{3}\right)$ is -1.019 which means that every $1 \%$ increase in the amount of consumption expended will reduce the saving desire by $0.198 \%$. The value of education level $\left(\mathrm{X}_{4}\right)$ is 0.452 , which means that every $1 \%$ increase in the level of education then the saving desire variable will increase by $0.423 \%$.

\section{T-test}

The significance test of individual parameters (statistical test $\mathrm{t}$ ) is used to determine whether in the regression model, the independent variables partially have a significant effect on the dependent variable. To determine the value of $t$ statistics can be used a significant level of $5 \%$. In accordance with the regression results and variables that affect saving desires can be accepted statistically then the following tests are carried out; If tcount $<$ ttable then partially the independent variable has an effect on the dependent variable and $\alpha<0,05$ which means significant.
If tcount $<$ ttable, then the independent variable partially does not affect the dependent variable and $\alpha>0.05$, which means it is not significant. Based on table $\mathrm{t}$, then get $\mathrm{t}$ table $=\mathrm{t}$ $(\alpha / 2 ; n-k-1)=t(0,025 ; 95)=1,985$. Based on the results of processed data, the results obtained t-count of:

1. Age variable $\left(\mathrm{X}_{1}\right) \mathrm{t}$ count $=-1.140$ and $\alpha=$ 0.257. Then $-1,140<1,985$ and $0.257>0.05$. This means that the $\mathrm{H}_{1}$ hypothesis which states that age has a positive and significant effect on saving desires is rejected. These results indicate that there is no influence of age on saving desires.

2. Income variable $\left(\mathrm{X}_{2}\right)$ value of $\mathrm{t}$ count $=$ 1.248 and $\alpha=0.215$ Then $1,248<1,985$ and 0.215 0.05. This means that the $\mathrm{H}_{2}$ hypothesis which states income has a positive and significant effect on saving desires is rejected. These results indicate that there is no influence of age on saving desires.

3. Consumption variable $\left(\mathrm{X}_{3}\right)$ value of $\mathrm{t}$ count $=-4,952$ and $\alpha=0,000$. Then -5,151 $>$ 1,985 and $0,000<0.05$. This means that the $\mathrm{H}_{3}$ hypothesis which states consumption has a negative and significant effect on the desire to save is accepted.

4. Variable level of education $\left(\mathrm{X}_{4}\right)$ value of $\mathrm{t}$ count $=1.285$ and $\alpha=0.202$. Then 1.067 $<1.985$ and $0.289>0.05$. This means that the $\mathrm{H}_{4}$ hypothesis which states the level of education has a positive and significant influence on saving desires is rejected. These results indicate that there is no influence on the level of education on saving desires. 


\section{Adjusted R Square}

Adjusted R square is used to measure the magnitude of the contribution of independent variables to the dependent variable. To measure how much the independent contribution (age, income, consumption and level of education) to the dependent variable (saving desire) is used adjusted $\mathrm{R}$ square. Based on the results of calculations using IBM Statistic SPSS 23 in Appendix 10, the results of the adjusted $\mathrm{R}$ Square calculation are 0.278 or $\mathbf{2 7 . 8} \%$. This means that $27 \%$ of saving desires are caused by variables of age, wages, consumption and education level, while the remaining $73 \%$ are influenced by other variables not examined. According to Ghozali (2009) the determinant of efficiency for crossdata is relatively low due to the large variations between each observation.

Based on table 3 the results of the significant value of age variables are 0.257 which is greater than the value of 0.05 . This means that age variables have no significant effect on saving desires. This result is not in accordance with the initial hypothesis which states that age has a positive and significant influence on saving desires. The argument is that they assume that as they grow older, their needs and desires increase. This can be seen from their consumptive lifestyle, judging from their income they tend to be used for everyday life, if there are new residues used to save. While the negative influence is that in this study it was found that the research subjects who were younger (age range 20-30 years) amounted to more than the study subjects who were older (age range 31-40 years). This result is supported by the study of Lea, Tarpy \& Webley (1987) who said one of the factors that increases saving behavior is age. Where older individuals will increasingly improve their saving behavior in preparation for the future, in contrast to individuals who are still young. Young people tend to borrow more money than to save if they have not reached the peak of their income.

Based on table 3 the results of the significant value of the income variable is equal to 0.215 which is greater than the value of 0.05 . This means that income variables have no significant effect on saving desires. This result is not in accordance with the initial hypothesis which states that age has a positive and significant influence on saving desires. From these results it can be interpreted that the income earned does not affect someone's desire to save. This is because the income they earn is prioritized by workers for consumption needs, so that if there is any leftover money they will just save. The results of the study are in line with the research of Ubaidillah (2019) which states that the non-influential causes of income towards saving desires because someone who has more income will be more able to be used to meet current needs or daily needs. someone, the higher the desire to consume.

Based on table 3 the results of the significant value of the consumption variable is o.ooo which is smaller than the value of 0.05 . This means that consumption variables have a significant influence on saving desires. These results are in accordance with the initial hypothesis which states that age has a negative and significant influence on saving desires. This result is seen from the suitability of the sign, in accordance with the initial hypothesis and in line with the simple economic thinking of a consumer household as an economic actor, where they will set aside their income or 
save if their daily needs are met. The argument in this study is that someone's consumption expenditure is influenced by his income, and tends to fulfill or meet his daily needs so that they only save if there is a residual consumption from the income they receive. has an influence on MPS. According to Sabarina, a consumptive lifestyle and citizens must be able to allocate income in accordance with the needs, prioritizing needs rather than desires.

Based on table 3 the results of the significant value of the education level variable is equal to 0.289 which is greater than the value of 0.05 . This means that education level variables have no significant effect on saving desires. This result is not in accordance with the initial hypothesis which states that the level of education has a positive and significant influence on the desire to save. The argument in this study is that because of their education which is majority of high school graduates and unmarried and do not have the desire to continue their education, they have the idea that the remaining income they save or the tube includes everything and is not grouped. Of the 100 respondents who filled out the questionnaire, only around $20 \%$ had special savings for education, most of them were married and the savings were specifically for their children. This is in accordance with the opinion of Gedela (2012) which reveals that one's level of education will not affect the desire to save individual households. Because, regardless of the level of education that someone has achieved, both high and low, someone's education will not affect his saving behavior, because he will still think about the future.

\section{CONCLUSION}

Based on data analysis and discussion of the results of the study, it can be concluded that, income and education level have a positive and not significant influence on saving desires, consumption has a negative and significant influence on saving desires. While age has a negative and not significant effect on the desire to save the textile industry labor force in Semarang Regency.

Based on the results of data analysis and discussion of the results of research, it can be suggested that optimizing the increase in labor savings in the textile industry can be done by consuming it as needed and reducing expenditures that are considered less important or reducing consumptive behavior by making monthly planning so that consumption is controlled and the amount of savings can be increased so that it is more intensive about the benefits of saving for all layers of labor and the benefits of saving can be felt. And for the next researcher it is suggested to analyze other variables that have not been done in this research. For example gender, wealth owned, occupation, tastes or desires, marital status, number of family dependents, family circumstances, education, just in case or frugality, and interest rates.

\section{REFERENCES}

Ahmad, M., \& Asghar, T. (2002). Estimation of Saving Behaviour in Pakistan Using Micro Data. The Lahore Journal of Economics, 9(2), 73-98.

Apriliyanto, Moch Rizkhi. Rusdarti. (2018). Analisis Penyerapan Tenaga Kerja Industri Tekstil dan Produk Tekstil di Provinsi Jawa tengah. Economics Development Analysis Journal. Volume 7 No.4 Hal 374-383. Semarang: Universitas Negeri Semarang.

Badan Pusat Statistika Jawa Tengah. (2017). Jumlah Tenaga Kerja. Jawa Tengah: BPS Jawa tengah. 
Bakti, T. Diana, Rakhmat Sumanjaya, Syahrir Hakim Nasution. (2011). Pengantar Ekonomi Makro, USU Press, Medan.

Basuki, A. T. \& Prawoto, N. (2016). Analisis Regresi dalam Penelitian Ekonomi dan Bisnis. Jakarta: PT Rajagrafindo Persada.

Cronqvist \& Siegel. (2011). The Origins of Savings Behavior: Journal of political economy. Vol 123, No 1.

Dewanti, Nike Putri. (2011). Faktor - Faktor yang Mempengaruhi Hasrat Masyarakat Untuk Menabung (Studi Kasus Di Desa Landungsari Kecamatan Dau Kabupaten Malang. Skripsi. Fakultas Ekonomi. Universitas Muhammadiyah Malang.

Dinas Tenaga Kerja Kabupaten Semarang. 2018. Data Jumlah Tenaga Kerja Industri Tekstil dan Produk Tekstil di kabupaten Semaranng. DISNAKER: Kabupaten Semarang.

Gedela. (2012). Determinants of Saving Behaviour in Rural and Tribal Households. International Journal of Research in Social Sciences, 2(3), 108128.

Ghozali, Imam. (2009). Ekonometrika Teori, Konsep dan Aplikasi dengan SPSS 17. Semarang: Badan Penerbit Universitas Diponegoro.

Ghozali, Imam. (2013). Aplikasi Analisis Multivariate dengan Program SPSS. Edisi Ketujuh. Semarang: Badan Penerbit Universitas Diponegoro.

Handayani, Tri. Suyanto. (2016). Hubungan Eq, Pengetahuan Kewirausahaan, Dan Hasrat Marginal Menabung, Dengan Motivasi Berwirausaha Mahasiswa Pendidikan Ekonomi. Jurnal Pendidikan IPS. Vol, 3. No, 1.

Hasibun. H, Malayu SP. (2011). Dasar-dasar Perbankkan, Jakarta: PT Bumi Aksara.

Imami, Sabarina Lutfiatul. (2014). Analisis Hasrat Konsumsi Marginal pada Warga Rt.o3 Rw.10 Kelurahan/Desa Kebonsari Kulon Kecamatan Kanigaran Tahun 2009-2013 Kota Probolinggo. Skripsi. Fakultas Keguruan dan Ilmu Pendidikan. Universitas Jember.

Lea, S. E. G., Tarpy, R. M., \& Webley, P. (1987). The individual in the economy. Journal. United States of America: Cambridge University Press.

Lee, Jae Min \& Sherman D. Hanna. (2015). Savings Goals and Saving Behavior From a Perspective of Maslow's Hierarchy of Needs. Journal of Financial Counseling and Planning. Vol 26, No 2, 129-147.
Prasetyo, P. Eko. (2016). Fundamental Makro Ekonomi. Yogyakarya: Beta Offset.

Prasetyo, P. Eko. (2015). Kesiapan Industri Tekstil dalam Mendukung Poros Maritim dan Peningkatan Daya Saing. Artikel Seminar Nasional. Universitas Negeri Semarang.

Prasetyo, P. Eko. (2017). Productivity of Textile Industry and Textile Products in Central Java. JEJAK: Jurnal Ekonomi dan Kebijakan. Volume 10 No. 2 Hal 257-272. Semarang: Universitas Negeri Semarang.

Rengarajan, V., Sankararaman, G., Kalyana Sundaram, M., Mohamed Rizwan, M., \& Mathew Paul Nibin, S. (2016). Influence of Demographic Variables on Saving Behaviour of Rural Households - A Study with Reference to Sriperumpudur, Chennai. Indian Journal of Science and Technology, 9(31).

Rohman, Ahmad Abdur, Sri Umi Mintarti Widjaja. (2018). Analisis Perilaku Konsumtif dan Perilaku Menabung Mahasiswa Penerima Beasiswa Bidikmisi di Jurusan Ekonomi Pembangunan Fakultas Ekonomi Universitas Negeri Malang Angkatan 2014. Jurnal Pendidikan Eknomi. Vol, 11. No, 2.

Rustow, D. A. (1967). A World of Nations: Problems of Political Modernization. Washington: The Brookings Instituion.

Sanusi, Anwar. (2011). Metodologi Penelitian Bisnis. Jakarta Selatan. Penerbit Salemba Empat.

Septiani. Dini. (2013). Faktor-Faktor yang Mempengaruhi Kecenderungan Menabung Marginal (Marginal Propensity to Save) Masyarakat Kelurahan Cibabat Kota Cimahi. Skripsi. Universitas Pendidikan Indonesia

Sevilla, C. G., (2007). Research Methods. Quezon City: Rex Printing Company.

Soediyono, R. (2001). Ekonomi Makro: Pengantar Analisis Pendapatan Nasional. Edisi Kelima. Yogyakarta: Liberty.

Sugiyono. (2017). Metode Penelitian Kuantitatif, Kualitatif, dan RED. Bandung: Alfabeta.

Sumastuti, Efriyani. (2009). Model tabungan Rumah Tangga Semarang. JEJAK: Jurnal Ekonomi dan Kebijakan. Volume o2 No.1 Hal 63-79. Semarang: Universitas Negeri Semarang.

Suparmoko. (2009). Pengantar Ekonomika Makro. Yogyakarta: BPFE

Supriyono, Maryanto. (2010). Buku Pintar Perbankan, Andi Yogyakarta, Bandung. 
Sutarno. (2005). Perilaku Menabung Rumah Tangga di Pedesaan (Studi Kasus di Kecamatan delanggu Kabupaten Klaten. Tesis. Magister Ilmu Ekonomi dan Studi Pembangunan. Universitas Diponegoro.

Thung, Chai, Ming., et. al. (2012). Determinants of saving behaviour among the university students in Malaysia. Journal. Malaysia: University Tunku Abdul Rahman.

Todaro, Michael. P., Sthephen C. Smith. (2007). Pembangunan Ekonomi di Dunia Ketiga. (Terjemahan: Haris Munandar). Jakarta: Penerbit Erlangga.
Ubaidillah, Hisyam Lathif. Nadia Asandimitra. (2019). Pengaruh Demografi, dan Literasi Keuangan terhadap Perilaku Menabung Masyarakat di Kabupaten Sidoarjo. Skripsi. Fakultas Ekonomi. Universitas Negeri Surabaya.

Veitzhal, Rivai. Sofyan Basir. Saworno Sudarto. \& Arifiandy Permata Veithzal. (2012). Comemercial Bank Management (Manajemen Perbankan dari Teori ke Praktik). Rajagrafindo Persada: Jakarta.

Wahidah, Nurul. (2016). Hubungan Persepsi Terhadap Masa Pensiun dengan Perilaku Menabung pada Pekerja Usia Dewasa Awal. Skripsi, Fakultas Psikologi. Universitas Muhamadiyyah Malang. 